\begin{tabular}{lccc} 
VERSITA & GOSPODARKA & SUROWCAMI & MINERALNYMI \\
\hline \multirow{2}{*}{ Tom 29} & 2013 & Zeszyt 1 \\
& & DOI 10.2478/gospo-2013-0010 &
\end{tabular}

MARIA KUSNIEROVA*, MARIA PRASCAKOVA*,

\title{
Thermal synthesis of black coal fly ash and gibbsite
}

\section{Introduction}

The expansion of mining and raw materials processing faces the generation of new materials. Directions of economic use of fly ash were presented in numerous papers,e.g. (Piotrowski, Uliasz-Bocheńczyk 2008). New technologies and materials have been created. Such materials produced from wastes and different additives are of composite character. Composition, genesis and processing of primary raw materials and products classically used in the industry can influence the qualitative and technological features of these composites. This was the reason for creation of a new research area referred to as "technolithology" (Gregerova 2004). Streamlining the industrial utilization of fly ashes from power production should be a motivation for new mullite type technolite production. Mullite is one of the basic refractory components produced by thermal transformation of natural polymorphous $\mathrm{Al}_{2} \mathrm{SiO}_{5}$ modifications (Berry, Mason 1987; Buchner, Schliebs et al. 1991; Hankyr, Kutzendorfer 2008; Karklit, Tichonova 1974). In nature, mullite is created in zones rich in Al, above all in the sillmanite, andalusite, cyanite, and topaz form, and as a consequence of its contact with the high temperatures of lava streams. The temperature of thermal transformation of the

* Institute of Geotechnics of Slovak Academy of Sciences Watsonova, Kosice, Slovak Republic; e-mail: kusnier@saske.sk; prascak@saske.sk

** VSB-Technical University of Ostrava, Faculty of Mining and Geology, ICT - Institute of Clean Technologies for Mining and Utilization of Raw Materials for Energy Use, Ostrava-Poruba, Czech Republic; e-mail: vladimir.cablik@vsb.cz

*** Instytut Gospodarki Surowcami Mineralnymi i Energią PAN, Kraków, Poland; e-mail: ajar@min-pan.krakow.pl 
aforementioned alumosilicates in mullite is around $1300^{\circ} \mathrm{C}$ (Berry, Maqson 1987). Also, other alumosilicates should be transformed into mullite, e.g. talc (Buchner, Schliebs et al. 1991; Dana, Das 2004; Karklit, Tichonova 1974; Kusnierova, Szabova 1976), but only in appropriate stoichiometric ratio of Al and Si of 3:2 (Hankyr Kutzendorfer 2008; Jung, Park et al. 2001).

\section{Materials and methods}

In experimental part of this study, fly ash from the heating plant Košice was used without pretreatment. The chemical composition is shown in the Table 1.

TABLE 1

Chemical composition of examined fly ash

Skład chemiczny badanych lotnych pyłów

\begin{tabular}{||c|c|c|c|c|c|c|c|c|c|c|c||}
\hline $\begin{array}{c}\text { Annealing lost } \\
(\%)\end{array}$ & $\begin{array}{c}\mathrm{SiO}_{2} \\
(\%)\end{array}$ & $\begin{array}{c}\mathrm{Al}_{2} \mathrm{O}_{3} \\
(\%)\end{array}$ & $\begin{array}{c}\mathrm{Fe}_{2} \mathrm{O}_{3} \\
(\%)\end{array}$ & $\begin{array}{c}\mathrm{CaO} \\
(\%)\end{array}$ & $\begin{array}{c}\mathrm{TiO}_{2} \\
(\%)\end{array}$ & $\begin{array}{c}\mathrm{MgO} \\
(\%)\end{array}$ & $\begin{array}{c}\mathrm{Na}_{2} \mathrm{O} \\
(\%)\end{array}$ & $\begin{array}{c}\mathrm{K}_{2} \mathrm{O} \\
(\%)\end{array}$ & $\begin{array}{c}\mathrm{P}_{2} \mathrm{O}_{5} \\
(\%)\end{array}$ & $\begin{array}{c}\mathrm{S}_{\text {total }} \\
(\%)\end{array}$ & $\mathrm{pH}$ \\
\hline \hline 15.5 & 47.10 & 20.86 & 8.83 & 23.80 & 0.76 & 1.21 & 0.78 & 2.14 & 0.35 & 0.15 & 12.4 \\
\hline
\end{tabular}

Based on the XRD analysis of the fly ash sample, the dominant phase in the fly ash were amorphous vitric phases. Other identified minerals were as follows: quartz, cristobalite, anhydrite, feldspar, corundum, magnetite, hematite, and graphite.

The $\mathrm{Al}$ additive chosen for this study was pure $\mathrm{Al}(\mathrm{OH})_{3}$ with a composition of $65.3 \%$ $\mathrm{Al}_{2} \mathrm{O}_{3}$ and $34.7 \% \mathrm{H}_{2} \mathrm{O}$.

The composite mixtures preparation was based on the 3 different mixing ratios of the fly ash and gibbsite (ratio of 2:1, 1.5:1, 1:1). It was assumed there were similar stoichiometric ratios of $\mathrm{Al}_{2} \mathrm{O}_{3}$ and $\mathrm{SiO}_{2}$ as in the mullite.

The mixtures of both of the components were consequently homogenized for 10 minutes and mechanically activated for 10, 15, and 30 minutes in a planetary mill.

The prepared, blended products were then thermally treated at 850,1050 , and $1500^{\circ} \mathrm{C}$. Analysis of the newly acquired materials indicated the presence of mullite and corundum components that are the basis of refractory materials.

The process of thermal transformation at 850,1050 , and $1500^{\circ} \mathrm{C}$ was evaluated by XRD analysis. Also added to the process of mullitization was inert, standard-pure $\mathrm{ZnO}$ (5\% weight) with the aim of quantifying the amorphous components and newly-produced phases in the composite mixtures. The samples were homogenised with this standard by micro-milling and consequently closed in the glass cuvette. Measurement was provided by a fully automatic diffraction meter URD-6 (Rich Seifert-FPM, Germany) under the following conditions: emission of $\mathrm{CoK} / \mathrm{Ni}$ rejecter, potential of $40 \mathrm{kV}$, ampere of $35 \mathrm{~mA}$, step mode 
$0.05^{\circ} 2$ theta with the step time of $3 \mathrm{~s}$, and digital processing of the measured data. The measuring and results were evaluated using the software RayfleX (RayfleX ScanX and RayfleX Analyze, 2.289 version).

\section{Results and discussion}

From the phases composition point of view, the elementary qualitative-quantitative parameters of the prepared composite materials are shown in Tables $2-5$. The results of the thermal transformation of basic fly ash components are shown in Table 2. The changing temperature influenced the content of amorphous phases of the fly ash. The mullite contents at $850^{\circ} \mathrm{C}$ decreased temporarily and the metastabile corundum structures were formed. However, at the next temperature level of $1050^{\circ} \mathrm{C}$, the mullite content increased to double the original sample value. The total content of refractory components increased at $1050^{\circ} \mathrm{C}$. At higher temperatures, the treated sample was totally melted and devaluated.

TABLE 2

The influence of thermal transformation on the phase's composition of examined fly ash

Wpływ obróbki termicznej na skład fazowy lotnych popiołów

\begin{tabular}{||c|c|c|c|c|c|c|}
\hline \hline \multirow{2}{*}{$\begin{array}{c}\text { Mixing ratio } \\
\text { fly ash: } \\
\text { additive }\end{array}$} & \multirow{2}{*}{$\begin{array}{c}\text { Milling time } \\
(\mathrm{min})\end{array}$} & $\begin{array}{c}\text { Transformation } \\
\text { temperature } \\
\left({ }^{\circ} \mathrm{C}\right)\end{array}$ & $\begin{array}{c}\text { Amorphous } \\
\text { phases }\end{array}$ & Mullite & Corundum & $\begin{array}{c}\text { Cofractory } \\
\text { material }\end{array}$ \\
\cline { 3 - 7 } & & 0 & 83.05 & 10.66 & - & 10.66 \\
\cline { 3 - 7 } $1: 0$ & \multirow{2}{*}{0} & 850 & 72.30 & 9.29 & 2.96 & 12.25 \\
\cline { 3 - 7 } & & 1050 & 64.30 & 22.70 & - & $\mathbf{2 2 . 7 0}$ \\
\cline { 3 - 7 } & & 1500 & \multicolumn{3}{|c|}{ Sample was melted and devaluated } \\
\hline
\end{tabular}

The qualitative-quantitative parameters of fly ash and gibbsite composite mixtures after thermal transformation experiments are shown in Tables 3-5. The influence of temperature, mechanical activation, and mixing ratio was traced in the creation of mullite-corundum phases in newly prepared composites.

Based on the results of this analysis, a comparison presented in Tables 3-5 suggests that a temperature of $850^{\circ} \mathrm{C}$ in all experiments increased the content of amorphous phases but decreased the content of refractory elements because of gibbsite dehydration. The following temperature rises increased the content of refractory materials: from $5 \%$ to $20-35 \%$ at a temperature of $1050^{\circ} \mathrm{C}$, and to $59-97.5 \%$ at $1500^{\circ} \mathrm{C}$. In technological terms, these results are sufficient for the refractory materials category, namely:

- Mullite not melted (melted) with the volume of mullite, cristobalite, corundum, and with $\mathrm{Al}_{2} \mathrm{O}_{3}$ content in the range of $60-85 \%$, and refractoriness up to $1960^{\circ} \mathrm{C}$. 
TABLE 3

The qualitative-quantitative composition of prepared composites at the mixing ratio of fly ash to gibbsite 2:1

TABELA 3

Jakościowo-ilosciowy skład kompozytów otrzymanych ze zmieszania lotnych pyłów i gibsytu w proporcji 2:1

\begin{tabular}{|c|c|c|c|c|c|c|}
\hline \multirow{2}{*}{$\begin{array}{c}\text { Mixing ratio } \\
\text { fly ash : } \\
\text { gibbsite } \\
\end{array}$} & \multirow{2}{*}{$\begin{array}{l}\text { Milling time } \\
\quad(\min )\end{array}$} & \multirow{2}{*}{$\begin{array}{c}\text { Transformation } \\
\text { temperature } \\
\left({ }^{\circ} \mathrm{C}\right) \\
\end{array}$} & \multicolumn{4}{|c|}{ Content (\%) } \\
\hline & & & $\begin{array}{c}\text { Amorphous } \\
\text { phases }\end{array}$ & Mullite & Corundum & $\begin{array}{c}\text { Amorphous } \\
\text { phases }\end{array}$ \\
\hline \multirow{4}{*}{$2: 1$} & \multirow{4}{*}{10} & 0 & 50.5 & 6.79 & - & 6.79 \\
\hline & & 850 & 86.2 & 4.82 & 0.85 & 5.67 \\
\hline & & 1050 & 69.2 & 14.54 & 7.45 & 21.99 \\
\hline & & 1500 & 39.8 & 56.8 & 2.35 & 59.15 \\
\hline \multirow{4}{*}{$2: 1$} & \multirow{4}{*}{15} & 0 & 39.4 & 4.61 & 1.72 & 6.33 \\
\hline & & 850 & 84.9 & 7.15 & - & 7.15 \\
\hline & & 1050 & 72.5 & 12.76 & 5.7 & 18.73 \\
\hline & & 1500 & 25.3 & 71.6 & 2.18 & 73.78 \\
\hline \multirow{4}{*}{$2: 1$} & \multirow{4}{*}{30} & 0 & 65.2 & 11.2 & - & 11.2 \\
\hline & & 850 & 86.0 & 4.39 & 1.06 & 5.45 \\
\hline & & 1050 & 60.6 & 17.4 & 9.95 & 27.35 \\
\hline & & 1500 & 36.4 & 60.7 & 1.89 & 62.59 \\
\hline
\end{tabular}

TABLE 4

The qualitative-quantitative composition of prepared composites at the mixing ratio of fly ash to gibbsite $2: 1.5$

TABELA 4

Jakościowo-ilościowy skład kompozytów otrzymanych ze zmieszania lotnych popiołów i gibsytu w proporcji 2:1,5

\begin{tabular}{|c|c|c|c|c|c|c|}
\hline \multirow{2}{*}{$\begin{array}{c}\text { Mixing ratio } \\
\text { fly ash : } \\
\text { gibbsite }\end{array}$} & \multirow{2}{*}{$\begin{array}{l}\text { Milling time } \\
\text { (min) }\end{array}$} & \multirow{2}{*}{$\begin{array}{c}\text { Transformation } \\
\text { temperature } \\
\left({ }^{\circ} \mathrm{C}\right)\end{array}$} & \multicolumn{4}{|c|}{ Content $(\%)$} \\
\hline & & & $\begin{array}{c}\text { Amorphous } \\
\text { phases }\end{array}$ & Mullite & Corundum & $\begin{array}{c}\text { Amorphous } \\
\text { phases }\end{array}$ \\
\hline \multirow{4}{*}{$2: 1.5$} & \multirow{4}{*}{10} & 0 & 37.4 & 4.61 & - & 4.61 \\
\hline & & 850 & 88.95 & 3.84 & 0.54 & 4.38 \\
\hline & & 1050 & 63.0 & 14.3 & 13.3 & 27.6 \\
\hline & & 1500 & 21.5 & 63.8 & 13.3 & 77.1 \\
\hline \multirow{4}{*}{$2: 1.5$} & \multirow{4}{*}{15} & 0 & 29.8 & 6.93 & - & 6.93 \\
\hline & & 850 & 85.65 & 3.88 & 1.64 & 5.52 \\
\hline & & 1050 & 64.9 & 13.9 & 11.32 & 25.22 \\
\hline & & 1500 & 32.0 & 55.5 & 11.29 & 66.8 \\
\hline \multirow{4}{*}{$2: 1.5$} & \multirow{4}{*}{30} & 0 & 31.6 & 6.82 & - & 6.82 \\
\hline & & 850 & 87.9 & 3.17 & 1.34 & 5.85 \\
\hline & & 1050 & 62.8 & 14.00 & 14.49 & 28.49 \\
\hline & & 1500 & 13.3 & 71.4 & 13.23 & 84.63 \\
\hline
\end{tabular}


TABLE 5

The qualitative-quantitative composition of prepared composites at the mixing ratio of fly ash to gibbsite 2:2

TABLELA 5

Jakościowo-ilosciowy skład kompozytów otrzymanych ze zmieszania lotnych popiołów i gibsytu w proporcji 2:2

\begin{tabular}{|c|c|c|c|c|c|c|}
\hline \multirow{2}{*}{$\begin{array}{l}\text { Mixing ratio } \\
\text { fly ash : } \\
\text { gibbsite }\end{array}$} & \multirow{2}{*}{$\begin{array}{l}\text { Milling time } \\
\quad(\mathrm{min})\end{array}$} & \multirow{2}{*}{$\begin{array}{c}\text { Transformation } \\
\text { temperature } \\
\left({ }^{\circ} \mathrm{C}\right)\end{array}$} & \multicolumn{4}{|c|}{ Content (\%) } \\
\hline & & & $\begin{array}{c}\text { Amorphous } \\
\text { phases }\end{array}$ & Mullite & Corundum & $\begin{array}{c}\text { Amorphous } \\
\text { phases }\end{array}$ \\
\hline \multirow{4}{*}{$2: 2$} & \multirow{4}{*}{10} & 0 & 30.0 & 5.4 & - & 5.4 \\
\hline & & 850 & 86.58 & 3.96 & 1.44 & 5.4 \\
\hline & & 1050 & 54.0 & 12.7 & 23.9 & 36.6 \\
\hline & & 1500 & 2.1 & 59.0 & 38.9 & 97.9 \\
\hline \multirow{4}{*}{$2: 2$} & \multirow{4}{*}{15} & 0 & 27.6 & 7.28 & - & 7.28 \\
\hline & & 850 & 89.5 & 3.3 & 1.53 & 4.83 \\
\hline & & 1050 & 63.4 & 10.38 & 17.96 & 28.34 \\
\hline & & 1500 & 17.7 & 52.5 & 27.9 & 80.4 \\
\hline \multirow{4}{*}{$2: 2$} & \multirow{4}{*}{30} & 0 & 29.8 & 5.41 & - & 5.41 \\
\hline & & 850 & 89.4 & 2.47 & 0.3 & 2.8 \\
\hline & & 1050 & 58.4 & 12.5 & 21.9 & 34.4 \\
\hline & & 1500 & 19.6 & 54.9 & 28.0 & 82.9 \\
\hline
\end{tabular}

- High aluminous chamotte with the volume of mullite, cristobalite, corundum, and with $\mathrm{Al}_{2} \mathrm{O}_{3}$ content in the range of $45-60 \%, 60-75 \%$, and up to $75 \%$. Refractoriness of this commercially used material is indicated by $\mathrm{Al}_{2} \mathrm{O}_{3}$ content in the temperature range of $1840-1950^{\circ} \mathrm{C}$ (Gregerova 2004).

The quality of the newly prepared composite is strongly influenced not only by temperature, but also by the mixing ratio of both components and the coherent stoichiometric ratio of major elements such as $\mathrm{Al}$ and $\mathrm{Si}$. The experiments did not confirm the positive influence of activation milling, which was different for each mixing ratio.

In terms of the mullite phase creation, the most suitable ratio was $2: 1$, the activation time 15 minutes, and the temperature $1500^{\circ} \mathrm{C}$, resulting in a composite with a $71.6 \%$ content of mullite.

In terms of the corundum phase creation, the most suitable ratio was $2: 2$, the activation time 10 minutes, and the temperature $1500^{\circ} \mathrm{C}$, resulting in a composite with a $38.9 \%$ content of corundum. The same conditions were optimal for the maximal mass yield of high refractory components of mullite and corundum.

The maximal thermal transformation was noted for fly ash and gibbsite at a ratio of 2:2. The newly prepared composite contained 59\% mullite and $38.9 \%$ corundum, with a total content of refractory components of $97.9 \%$. 


\section{Conclusion}

The results presented here confirmed that black coal fly ash possesses the potential to be used as a component in refractory composite materials. The experiments conducted for this study suggested that black coal fly ash used as a composite admixture in the preparation of the technolite types can substitute the primary raw materials.

\section{Acknowledgement}

This research has been carried out within the SGA project No. 2-0086-10, SRDA projects No. SK-PL-0048-09 and No. SK-CZ-0146-09, mobility project No. MEB0810142, and the project "Institute of clean technologies for mining and utilization of raw materials for energy use", reg. no. CZ.1.05/2.1.00/03.0082, supported by the Research and Development for Innovations Operational Programme financed by Structural Funds of the European Union and by means of the state budget of the Czech Republic. We are also grateful for funding which was received through the Centre of Excellence for Integrative Research of the Earth's Geosphere (ITMS 26220120064) which is supported by the Operational Program "Research and Development" and financed through the European Regional Development Fund.

\section{REFERENCES}

Berry ey al. 1987 - B erry L.G., Mas on B., Dietrich R.V., 1987 - Mineralogy. Moskva. Mir.

Büchner et al. 1991 - Büchner W., Schliebs R., Winter G., Büchel K.H., 1991 - Průmyslová anorganická chemie. SNTL, Praha, p. 568.

Dana et al. 2004 - Dana K., Das S., Kumar 2004 - Effect of substitution of fly ash for quartz in triaxial kaolin-quartz-feldspar system. Journal of the European Ceramic Society. Vol. 24, p. 3169-3175.

Gre gorowva M., 2004 -Technolitologie. http://www.petrol.sci.muni.cz

Hankýr̆ V., Kützendörfer J., 2008 - Technologie keramiky. Silikátový svaz. Praha.

Jung et al. 2001 - Jung J.S., Park H.C., Stevens R., 2001 - Mullite ceramics derived from coal fly ash. Journal of Materials Science Letters. p. 1089-1091.

Karklit A.K., T i chonova L.A., 1974 - Ogneupory iz vysokoglinozemistovo syrja. Meralurgia. Moskva

Kušnierová et al. 2010 - Kušnierová M., Praščáková M., Matýs ek D., F e čko P., 2010 - Energetic wastes as an equivalent for primary nonmetallic materials. Proc of the 14th International Conference on Environment and Mineral Processing. Part II., Ostrava, p. 35-38.

Kušnierová M., Szabová J., 1976 - Správa o úprave suroviny z locality „Potok Kapka”. Geologický prieskum š.p., príloha 2, manuscript.

Piotrowski Z., Uliasz-B ocheńczyk A., 2008 - Możliwości gospodarczego wykorzystania odpadów z kotłów fluidalnych. Gospodarka Surowcami Mineralnymi 2, 73-85. 
TERMICZNA SYNTEZA POPIOŁÓW Z WEGLA KAMIENNEGO I GIBBSYTU

\section{Słowa kluczowe}

Popioły węgla kamiennego, gibbsyt, mulit

\section{Streszczenie}

Mulit jest minerałem glinokrzemianowym o wyjątkowych właściwościach i odgrywa istotną rolę w wytwarzaniu ogniotrwałych wyrobów. W przyrodzie występuje bardzo rzadko i z tych też względów jest otrzymywany na drodze syntezy z naturalnych pierwotnych surowców (silmanit, andaluzyt, cyjanit), ale jego głównym źródłem jest kaolinit.

Proces mulityzacji jest związany z przemianą minerałów glinu w mulit. Efektywność przemiany związków glinu w mulit jest zawsze mniejsza w stosunku do teoretycznej zawartości $\mathrm{Al}_{2} \mathrm{O}_{3}$ w tworzywie. Proces przemiany zależy od obecności mineralizatorów, temperatury, czasu wypału itp.

Celem tej pracy była ocena możliwości wykorzystania odpadów energetycznych zawierających takie składniki jak Al i Si. Do skorygowania składu stosowano glin w postaci gibbsytu. Przebadano wpływ różnych stosunków popiołu lotnego i gibbsytu jak i wpływ temperatury przemiany na skład mineralny (fazowy) przygotowanych kompozytów typu mulitu.

THERMAL SYNTHESIS OF BLACK COAL FLY ASH AND GIBBSITE

Key words

Black coal fly ash, gibbsite, mullitization

\section{Abstract}

Mullite is an aluminosilicate mineral with exceptional properties, and plays an important role in refractory ware production.

Its occurrence in nature is very rare; it is therefore synthesized from various natural, primary raw minerals (sillimanite, andaluzite, cyanite, etc.), but the main source is kaolinite.

The process of mullite formation is connected with the transformation of alumina minerals into $3 \mathrm{Al}_{2} \mathrm{O}_{3} \mathrm{SiO}_{2}$. The effectiveness of transformation of aluminum compounds into mullite is not adequate to the theoretical content of $\mathrm{Al}_{2} \mathrm{O}_{3}$ in the material. The transformation process depends on the presence of mineralizers, temperature, time of firing, etc.

The aim of this work was the assessment of potential uses of energetic waste including such components as $\mathrm{Si}$ and Al. To correct the material composition, an Al additive in the form of gibbsite was used. This study also investigated the influence of different mixture ratios of fly ash and gibbsite, and the influence of transformation temperature on the phase composition of the prepared mullite type composite. 
